\title{
Impact of the Cognitive Image on Destination Loyalty: A Parallel Mediation Technique
}

\author{
Nushrat Nahida Afroz" \\ Abu Naser Ahmed Ishtiaque ${ }^{2}$ \\ Mawlana Bhashani Science and Technology University Tangail, Bangladesh \\ University of Dhaka, Bangladesh
}

\begin{abstract}
This study proposes a parallel mediation model in which the interrelationship of the cognitive image, satisfaction, and perceived value influences destination loyalty. A convenience sample of 603 observations was collected in Cox's Bazar, Bangladesh. Structural equation modelling was utilized to assess the model. In the study, perceived values and satisfaction directly impact destination loyalty. However, the cognitive image does not affect destination loyalty. Both satisfaction and perceived value mediate between cognitive image and destination loyalty. The data were collected during the peak season of tourism in Cox's Bazar. Thus, the results cannot be extrapolated to off-peak seasons. Because postulated links have received little attention, the study helps advance the conceptual underpinnings, particularly in light of Cox's Bazar. There is merit to this study in that it demonstrates the parallel mediating effect of satisfaction and perceived value between cognitive image and destination loyalty, which has received little attention in previous tourism literature, especially in the developing country context.
\end{abstract}

Keywords: Cognitive Image, Perceived Value, Satisfaction, Destination Loyalty

Corresponding author: Nushrat Nahida Afroz; E-mail: nnafroz20@yahoo.com DOI: https://doi.org/10.37227/ITHJ-2022-01-718

\section{Introduction}

Tourism is a significant source of government revenue all around the world (Manzoor et al., 2019). Destinations may also be thought of as elements that significantly contribute to a country's tourism revenue (Basaran, 2016). Since tourist consumption has been strong in the prior two decades, the importance of destinations has grown more than specific attractions (Ozturk \& Qu, 2008). As a consequence, visitors to a place are seeking a variety of experiences. So, a journey is no longer a product but rather a collection of various services, typically offered by some organizations with different purposes (Kozak, 2003). Therefore, tourists' happiness with all of the services available at the destination is required to attain overall destination satisfaction (Chen \& Kerstetter, 1999). Knowing the destination image is crucial for predicting visitor satisfaction and behavior from this perspective. 
Several studies have found that the image of a destination influences visitor behavior (Mathieson \& Wall, 1982). Tourist behaviors might involve selecting a destination to visit, evaluating that decision, and planning future activities (Cohen et al., 2013). There may be additional assessments involved, such as a review of the travel experience while on the trip, the desire to return, and a willingness to recommend the place in the future (Chen \& Tsai, 2007). Therefore, the destination image influences the tourist decision-making process (Gartner, 1989) and post-decisional behavior (Bigne et al., 2001). The image may be one of the most crucial aspects of tourists' decision-making and destination-selection processes. As the competition among destinations heats up, destinations emphasize their image as a source of competitive advantage (Konecnik, 2002).

Thus, studying how tourists choose a destination is important (Martin \& Bosque, 2008). Nazir et al. (2021) stressed the importance of the tourism destination image. Besides, destinations need new strategies to attract tourists in the service-dominated marketing industry. Because tourism industry profits increase when tourists visit, and marketing expenses are reduced (Alegre \& Juaneda, 2006).

Using tourist behavioural models, a theoretical model links cognitive image, perceived value, tourist satisfaction, and destination loyalty were proposed in this model. This model broadens our understanding of the knowledge theoretically and methodologically by incorporating cognitive image, perceived value, visitor satisfaction, and destination loyalty. This framework is being tried in Cox's Bazar, Bangladesh's longest sea beach. Cox's Bazar has been designated a tourism hotspot due to its exceptional uninterrupted coastline, golden sand, and least congested location. Structured equation modelling (SEM) is used to investigate the link between these components. SEM is frequently used in academic and social science research because it enables the simultaneous exploration of multivariate dependent links (Hair, Ringle, \& Sarstedt, 2011). Study participants were tourists in Cox's Bazar.

A model was developed to analyze theoretical and empirical data about the relationship between cognitive image, perceived value, tourist satisfaction, and destination loyalty and extend our understanding of destination loyalty. There are six distinct research concerns examined in this study: 1) Is there an effect of cognitive image on perceived value? (2) Is there a link between cognitive image and satisfaction? (3) Does the cognitive image impact destination loyalty? (4) Is there a link between visitor satisfaction and destination loyalty? (5) Is satisfaction a mediator in the link between cognitive image and destination loyalty? Also, (6) Is perceived value a mediator in the influence of cognitive image and destination loyalty?

\section{Destination Image}

\section{Literature Review}

Tourism destination images are bundles of perceptions or thoughts about a destination. Destination image is an essential concept that impacts visitor decisions (Chen \& Phou, 2013). Prior investigation has revealed that destination image is a hot topic in tourism literature (Yung et al., 2021) and scholars have attempted to develop a theoretical model for it employing a variety of methodologies. Various researches on the notion of DI have revealed an inherent alliance on the real value of destination marketers; however, there has been very little agreement on the conceptualization and dimension of DI due to the complexity, subjectivity, and enigmatic nature (Song et al., 2013). Crompton (1979) defines DI as the aggregate of beliefs, ideas, and perceptions that a person has about a 
destination. This definition emphasizes the individual but other definitions given by other researchers define it by the image shared by the group of people (Jenkins, 1999).

Echtner \& Ritchie, (1993) defined destination image as a combination of attributebased factors and holistic perspectives. Baloglu \& McCleary (1999a) also examined the destination image into cognitive and affective components commonly found in tourism literature. The cognitive image relates to thoughts and information about the features of a vacation location, whereas affective image refers to emotions or sentiments associated with the place (Gallarza et al., 2002). Only the cognitive image of Cox's Bazar was evaluated in this investigation. The significance of the destination image cannot be overstated due to its effect on the visitor decision-making (Echtner \& Ritchie, 1993), subsequent evaluation, and post-purchase decision (Chen \& Tsai, 2007). In comparison, Chen \& Phou (2013) posited that destination image positively affects satisfaction and destination loyalty.

Various researches discovered a positive association between destination image, satisfaction, and loyalty (Jeong \& Kim, 2020). Chen \& Phou (2013); Gallarza \& Gil (2006) revealed the same results. According to Munhurrun et al. (2015), a higher destination image assures a greater perceived value. Therefore, the destination image could be considered a significant predictor of perceived value (Kim, Holland \& Han, 2013). Moreover, the destination image is positively associated with tourist satisfaction (Wang \& Hsu, 2010). In most studies, tourists' loyalty is related to the destination image (Tan \& Wu, 2016). Therefore, the destination's image is essential in influencing loyalty.

\section{Perceived Value}

Tourism perceptions of value are based on comparing the value of a destination versus the sacrifices or costs associated with it (Chi et al., 2020). According to the utilitarian paradigm, value scales consider monetary and non-monetary (Petrick, 2002). Li \& Petrick (2010) developed an integrated loyalty model that incorporated quality and value. However, (Chen \& Tsai 2007) used a three-item scale to assess value perception based on money, time, and effort. Several prior studies examined the interrelationships between perceived value, satisfaction, and loyalty. In most studies, perceived value strongly determines visitor satisfaction and behavioral intentions (Woodruff, 1997). Some researchers have found a direct and indirect link between perceived value and loyalty (Kim et al., 2013). Therefore, the importance of perceived value in fostering long-term connections with visitors cannot be underestimated. In conclusion, these research findings indicated that perceived value is a noteworthy predictor of satisfaction and loyalty.

\section{Satisfaction}

Satisfaction is defined as an evaluative opinion of a destination's products and services, and it is one of the essential phrases in today's commercial competition (Pavlic et al.,2011). Tourist satisfaction has been extensively researched for decades (Song et al., 2012). It is commonly considered that tourist satisfaction substantially influences their loyalty and likelihood of returning (Chen \& Tsai, 2007). For instance, pleased visitors may post favorable comments about the place, promote it to family and friends, and revisit a similar location next time (Chen et al., 2020). One of the most often utilized and important indicators of loyalty is satisfaction (Morgan \& Rego, 2006). As a result, satisfaction is the main concern for business strategy makers (Anderson et al. 1994). The bulk of prior research has shown that satisfaction positively influences destination loyalty (Hasan et

https://rpajournals.com/ithj 
al.,2019). As a result, it is widely accepted that tourist satisfaction is an important predictor of destination loyalty (Allameh et al., 2015).

\section{Loyalty}

According to Oliver (1999), loyalty is the highest level of devotion. Tourist loyalty is completely interchangeable with behavioral intention (Sangipul, 2018). Positive word-ofmouth, referrals, and a willingness to buy or return have all been used to gauge Loyalty (Wendy et al., 2015).

This study highlights three antecedents as important characteristics for the theoretical framework: destination image, perceived value, and visitor satisfaction. As previously stated, the image of a location determines its perceived value, satisfaction, and loyalty. Perceived value impacts satisfaction and loyalty, while tourist satisfaction is crucial for loyalty (Mohamad et al., 2019). Furthermore, building long-term relationships with visitors has become a key business success. Customers who are loyal to a company are seen as valuable assets. As a result, cognitive image perceived value and satisfaction are the most critical elements influencing tourists' desire to revisit or recommend a destination (Jalilvand \& Samiei, 2012) and tourist loyalty.

\section{Role of Perceived Value and Satisfaction as a Mediator}

Destination image and loyalty are directly or indirectly connected in tourist literature (Kanwel, 2019). As mediators, perceived value and satisfaction, according to some academics, are likely to impact loyalty. (Wang et al., (2017a); Jeong \& Kim, (2020) discovered the role of satisfaction as a mediator between destination image and destination loyalty.

H1: Cognitive Image positively influences destination loyalty

$\mathrm{H} 2$ : Cognitive Image positively influences perceived value

H3: Cognitive Image has a positive influence on satisfaction

H4: Perceived value has a positive influence on destination loyalty

H5: Perceived value has a positive influence on satisfaction

H6: Satisfaction has a positive influence on destination loyalty

H7: Perceived value mediates between Cognitive Image and destination loyalty

H8: Satisfaction mediates between perceived value and destination Loyalty

H9: Perceived value mediates between Cognitive Image and satisfaction

H10: Satisfaction mediates between Cognitive Image and destination loyalty

H11: Perceived value and satisfaction positively and sequentially mediates between Cognitive Image and destination loyalty. 
Figure 1 shows the proposed theoretical model.

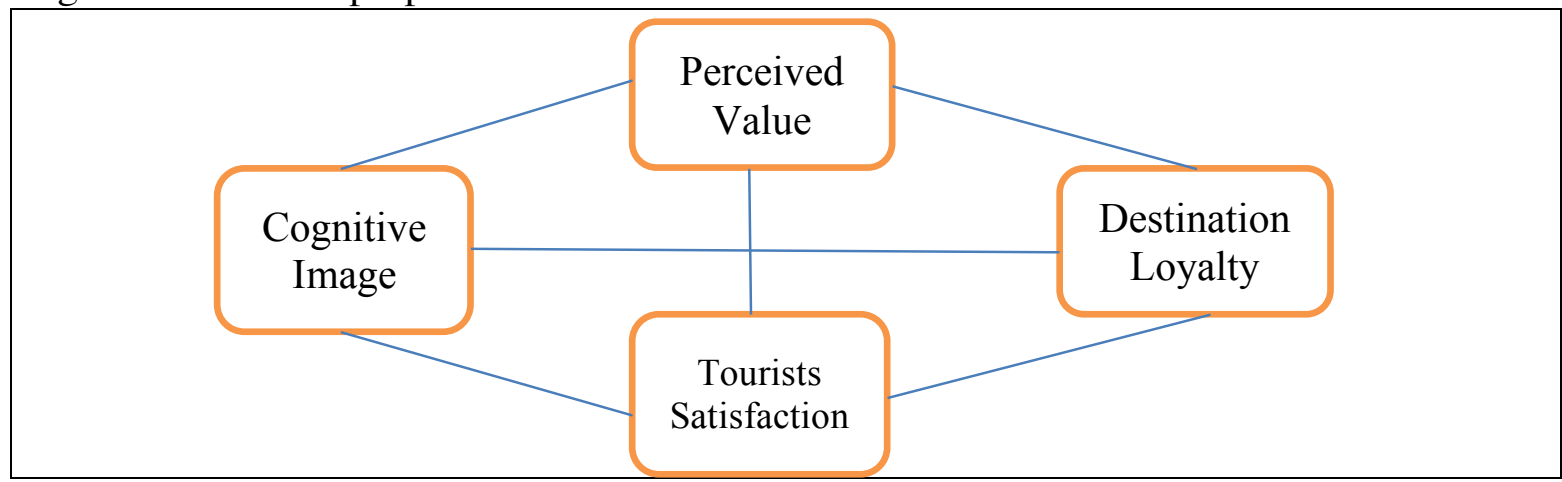

\section{Research Setting}

\section{Research Methodology}

Cox's Bazar has been selected as a survey site. This is a tourism hotspot and a popular holiday destination. Cox's Bazar is 152 Kilometres south of Chittagong in Bangladesh. In Cox's Bazar, tourism seems to be the main source of revenue (Bhattacharjee et al., 2019). Tourism is economically and socially important for Cox's Bazar (Abdullah et al., 2019). From November to March, almost two million visitors visit Cox's Bazar during the peak season. Tourists are primarily domestic tourists from all around the country. Labonee Beach is believed to be one of the country's most popular tourist destinations, with daily maximum visitor numbers reaching 30,000 (Kalam \& Hossen, 2018).

\section{Sample Design}

A causal research design was used in this study. The visitors to Cox's Bazar who were 18 years of age or older were the target group for this research. Several research papers have employed a non-probability sample strategy to research destination image in the lack of accurate data on travellers (Iordanova \& Stylidis, 2019). Numerous earlier research evaluated destination image using convenience sampling approaches (Chen \& Tsai, 2007). The empirical study was conducted in Cox's Bazar, Bangladesh, at the three most popular sea beaches, Laboni Point, Kolatali, and Inani Beach, during the winter season. Tourists flock to Cox's Bazar in droves during the winter months. Between November 2019 and February 2020, data was gathered in Cox's Bazar. A total of 630 questionnaires were delivered to those qualified to participate. The respondents completed 610 surveys, removing seven items due to incoherence. Finally, 603 requests were determined to be legitimate and were allocated to be assessed. The overall sample size of 603 is greater than the sample-to-item ratio (i.e., $17 \times 5=85$ ), the sample-to-variables ratio (i.e., $20 \times 4=80$ ), and the Krejcie and Morgan (1970) suggested threshold value 384 (Memon, 2020; Hair et al., 2017).

\section{Instruments for Conducting Surveys}

A closed-ended, self-administered questionnaire was used in this study to obtain the essential information from the respondents. Tourism research has widely used measures of the cognitive image, perceived value, satisfaction, and loyalty. Therefore, these constructs and demographic factors were incorporated into the survey questionnaire. Only three items were used to document tourists' impressions of cognitive image and adapted from the study of Baloglu \& McCleary (1999). The responses were assessed on a five-point Likert scale, 
with 1 indicating "strongly disagree," and 5 indicating "strongly agree." Tourist satisfaction was researched in order to determine the satisfaction of visiting tourists in Cox's Bazar.To gauge satisfaction, however, five items were used. Six items were derived from (Lee et al.,2007) to assess perceived value. The desire to suggest Cox's Bazar to others adapted from (Chiu et al., 2016); and the willingness to return to Cox's Bazar as a tourist site were adapted from (Bigne et al., 2005) to determine destination loyalty in this study. Several studies have used positive word of mouth or revisit intention to assess future behavior or loyalty among consumers. (Chen \& Tsai, 2007). Overall satisfaction was measured using a five-point Likert scale, with 1 denoting "strongly dissatisfied" and 5 expressing "strongly satisfied". With the aid of translation professionals, the questionnaire was translated into Bangla. Because the investigation was conducted in Cox's Bazar, Bengali is the native language of the respondents. Therefore, the questionnaire was translated for the interviewees' convenience. Respondents' age, gender, educational qualification, and visitation frequency were all queried to reveal the demographic profile of the participants.

\section{Results and Analysis}

Descriptive statistics have been developed based on the demographic information provided by visitors. The SEM was tested using confirmatory factor analysis (CFA). Structural equation modeling explored the relationship between destination image, perceived value, satisfaction, and destination loyalty. SPSS 15.0 (Statistical Package for the Social Sciences) and SmartPls 3.2.9 were used to conduct CFA and SEM.

\section{Demographic Profile}

First, the demographic profile of the visitors who took part in this survey is provided (Table 1). We deemed 603 questionnaires valid for further analysis. $369(61.2 \%)$ of the 603 responders were male, while $234(38.8 \%)$ were female. The majority of responders $(58.2 \%)$ were between 22 and 35, with nearly one-quarter (23.2\%) being between 36 and 50 . Only $2.2 \%$ were over the age of 65 .

The respondents' education levels were pretty high, with more than 176 of the respondents $(29.2 \%)$ being postgraduates (Masters and others), 133 respondents having bachelor degrees $(22.1 \%), 132$ having higher secondary certificate $(21.9 \%)$, and the rest of respondents having educational qualifications up to the secondary school certificate. According to the travel profiles of the respondents, 359 (59.5\%) were first-time tourists to Cox's Bazar; the rest of the tourists have a previous experience of Cox's Bazar 244 $(40.5 \%)$. However, the number of people visiting Cox's Bazar over two or more times is fascinating. 
Table 1: Demographic characteristics and percentage

\begin{tabular}{|c|c|c|}
\hline Characterisitcs & Categories & Percentage (\%) \\
\hline \multirow{4}{*}{ Age } & under 21 & 13.1 \\
\cline { 2 - 3 } & $22-35$ & 58.2 \\
\cline { 2 - 3 } & $36-50$ & 23.2 \\
\cline { 2 - 3 } & $51-60$ & 3.3 \\
\cline { 2 - 3 } & Above 65 & 2.2 \\
\hline \multirow{4}{*}{ Educational Qualification } & Male & 61.2 \\
\cline { 2 - 3 } & Female & 38.8 \\
\cline { 2 - 3 } & Post graduate & 29.2 \\
\cline { 2 - 3 } & Graduate & 22.1 \\
\cline { 2 - 3 } & University diploma & 8.5 \\
\cline { 2 - 3 } & Higher Secondary & 21.9 \\
\cline { 2 - 3 } & Certificate & 15.6 \\
\cline { 2 - 3 } & Secondary School & \\
\cline { 2 - 3 } & Certificate & 2.8 \\
\hline Number of visits & Others & 59.5 \\
\cline { 2 - 3 } & One Time & 23.2 \\
\cline { 2 - 3 } & Two Times & 10.0 \\
\cline { 2 - 3 } & Three Times & 7.3 \\
\hline
\end{tabular}

(N:B: $n=603 ;$ Spss output)

\section{Measurement Model}

This research adhered to Anderson and Gerbing's specifications (1988). Consequently, the internal consistency of the measuring concept was tested before analyzing the model of the postulated variables. Cronbach's alpha $(\alpha)$ values greater than 0.7 were discovered, suggesting that the scale demonstrates internal consistency (Hair et al., 2014). Similarly, convergent validity was assessed to ascertain the measure's validity. The composite reliability ranges from (0.839-0.879), showing the constructions' reliability (Fornell \& Larcker, 1981). The outer factor loadings should be more than 0.70 , although, in the case of an exploratory study, this value may be acceptable within 0.50-0.60 (Chin, 1998). The factor loadings in this study ranged from 0.640 to 0.877 and are significant. Due to low (less than .50) loadings, just one item (DL 2) was eliminated. Similarly, the average variance extracted above the 0.50 minimal requirement (Hair et al., 2014). (See: Table 2). 
Table 2: Constructs Reliability and Validity Assessment

\begin{tabular}{|c|c|c|c|c|c|c|}
\hline Constructs & $\begin{array}{l}\text { Measurement } \\
\text { Items }\end{array}$ & $\begin{array}{c}\text { Outer } \\
\text { Loadings }\end{array}$ & VIF & $\begin{array}{c}\text { Cronbach's } \\
\text { Alpha }\end{array}$ & $\begin{array}{l}\text { Composite } \\
\text { Reliability }\end{array}$ & $\begin{array}{c}\text { Average } \\
\text { Variance } \\
\text { Extracted } \\
\text { (AVE) }\end{array}$ \\
\hline \multirow{3}{*}{$\begin{array}{l}\text { Cognitive } \\
\text { Image }\end{array}$} & COG1 & 0.846 & 1.51 & \multirow[b]{3}{*}{0.764} & \multirow[b]{3}{*}{0.861} & \multirow[b]{3}{*}{0.675} \\
\hline & COG3 & 0.877 & 2.03 & & & \\
\hline & COG4 & 0.736 & 1.56 & & & \\
\hline \multirow{5}{*}{$\begin{array}{c}\text { Destination } \\
\text { Loyalty }\end{array}$} & DL1 & 0.723 & 1.4 & \multirow[b]{5}{*}{0.762} & \multirow[b]{5}{*}{0.839} & \multirow[b]{5}{*}{0.512} \\
\hline & DL3 & 0.640 & 1.29 & & & \\
\hline & DL4 & 0.777 & 1.73 & & & \\
\hline & DL5 & 0.743 & 1.72 & & & \\
\hline & DL6 & 0.687 & 1.48 & & & \\
\hline \multirow{4}{*}{$\begin{array}{l}\text { Perceived } \\
\text { Value }\end{array}$} & PV1 & 0.757 & 1.35 & \multirow[b]{4}{*}{0.793} & \multirow[b]{4}{*}{0.864} & \multirow[b]{4}{*}{0.614} \\
\hline & PV2 & 0.807 & 1.64 & & & \\
\hline & PV3 & 0.821 & 2.13 & & & \\
\hline & PV4 & 0.748 & 1.82 & & & \\
\hline \multirow[b]{5}{*}{ Satisfaction } & SAT1 & 0.753 & 1.74 & \multirow[b]{5}{*}{0.83} & \multirow[b]{5}{*}{0.879} & \multirow[b]{5}{*}{0.594} \\
\hline & SAT2 & 0.834 & 2.22 & & & \\
\hline & SAT3 & 0.79 & 2.04 & & & \\
\hline & SAT4 & 0.729 & 1.8 & & & \\
\hline & SAT5 & 0.742 & 1.6 & & & \\
\hline
\end{tabular}

(COG=Cognitive; PV=Perceived Value; SAT=Satisfaction and DL=Dtination Loyalty)

To establish discriminant validity, the value of the other variable was compared to the squared value of the average variance extract. According to this study, the squared root of the average variance extract had a greater value than the inter-construct correlation. As a result, the measurements have discriminant validity (Fornell \& Larcker, 1981). The HTMT values are shown in Table 3. The HTMT outperforms Fornell and Lacker, as well as crossloadings (Sahabuddin et al., 2021). The HTMT scores are below the recommended and preferred values of 0.85 and 0.90, respectively (Henseler et al., 2015). Furthermore, no confidence interval includes 1 . As a result, the measurement model's discriminant validity is confirmed (Hair et al., 2017). 
Table 3: Fornell and Lacker \& Heterotrait-Monotrait Ratio (HTMT)

\begin{tabular}{|c|c|c|c|c|}
\hline Constructs & $\begin{array}{l}\text { Cognitive } \\
\text { Image }\end{array}$ & $\begin{array}{l}\text { Destination } \\
\text { Loyalty }\end{array}$ & $\begin{array}{l}\text { Perceived } \\
\text { Value }\end{array}$ & Satisfaction \\
\hline $\begin{array}{l}\text { Cognitive } \\
\text { Image }\end{array}$ & 0.822 & & & \\
\hline $\begin{array}{l}\text { Destination } \\
\text { Loyalty }\end{array}$ & 0.239 & 0.716 & & \\
\hline $\begin{array}{l}\text { Perceived } \\
\text { Value }\end{array}$ & 0.265 & 0.496 & 0.784 & \\
\hline Satisfaction & 0.254 & 0.645 & 0.536 & 0.771 \\
\hline \multicolumn{5}{|c|}{ Heterotrait-Monotrait Ratio (HTMT) } \\
\hline \multicolumn{5}{|c|}{\begin{tabular}{l|l|l} 
Cognitive & & \\
Image & &
\end{tabular}} \\
\hline $\begin{array}{l}\text { Destination } \\
\text { Loyalty }\end{array}$ & 0.288 & & & \\
\hline $\begin{array}{l}\text { Perceived } \\
\text { Value }\end{array}$ & 0.327 & 0.612 & & \\
\hline Satisfaction & 0.3 & 0.792 & 0.633 & \\
\hline
\end{tabular}

Note: Values in bold represent the square root of AVE, and the rest of the constructs represents the correlations

\section{Structural Model}

The quality or strength of the structural model was assessed using the following criteria: (1) verifying collinearity; (2) Assessing model's predictive performance through $\left(\mathrm{R}^{2}\right)$ and the $\mathrm{Q}^{2}$ (Hair et al.,2017) (3) evaluation of the effect size $\mathrm{f}^{2}$, and (4) statistical significance and relevance of the path coefficients.

Collinearity Assessment: When employing PLS-SEM, VIF values more than or equal to 5 suggest the possibility of collinearity (Hair et al., 2019). Several studies, however, use alternative limitations, taking VIF values greater than 3.3 and even 5 into account (Diamantopoulos \& Siguaw, 2006; Hair et al.,2014). The results of the VIF evaluation show that there are no collinearity issues in this analysis (see Table 4).

Table 4. Variance Inflation Factor (VIF)

\begin{tabular}{|l|l|l|l|r|}
\hline & $\begin{array}{l}\text { Cognitive } \\
\text { Image }\end{array}$ & $\begin{array}{l}\text { Destination } \\
\text { Loyalty }\end{array}$ & $\begin{array}{l}\text { Perceived } \\
\text { Value }\end{array}$ & Satisfaction \\
\hline $\begin{array}{l}\text { Cognitive } \\
\text { Image }\end{array}$ & & 1.1 & 1 & 1.076 \\
\hline $\begin{array}{l}\text { Destination } \\
\text { Loyalty }\end{array}$ & & & & \\
\hline $\begin{array}{l}\text { Perceived } \\
\text { Value }\end{array}$ & & 1.44 & & 1.076 \\
\hline Satisfaction & & 1.43 & & \\
\hline
\end{tabular}

\section{Predictive Power of the Model}

$\mathrm{R}^{2}$ and $\mathrm{Q}^{2}$ were used to assess the model's validity. $\mathrm{R}^{2}$ begins by listing the model's strengths. R2 values of $0.25,0.50$, and 0.75 , respectively, imply poor, moderate, and strong 
prediction accuracy (Merli et al., 2019). The results are greater than the minimal threshold $\mathrm{R}^{2}$ of 0.1 , destination loyalty $\mathrm{R}^{2}$ of 0.45 , satisfaction $\mathrm{R}^{2}$ of 0.301 (near substantial), and perceived value $\mathrm{R}^{2}$ of 0.07 . (Weak). As a result, our model has a partial predictive ability for $\mathrm{R}^{2}$ (Table 5). A predictive model has a cross-validated redundancy of $\mathrm{Q}^{2}$ greater than 0 . This study's Stone-Geisser $Q^{2}$ criteria are greater than the specified cut off value (Table 5).

Table 5. Variance Explained and Cross-Validated Redundancy Index

\begin{tabular}{|c|c|c|}
\hline Endogenous Construct & $\mathrm{R}^{2}$ & $\mathrm{Q}^{2}$ \\
\hline Destination Loyalty & 0.45 & 0.218 \\
\hline Perceived Value & 0.07 & 0.041 \\
\hline Satisfaction & 0.301 & 0.169 \\
\hline
\end{tabular}

\section{Effect Size (f')}

By examining the shift in $\mathrm{R}^{2}$ induced by deleting an exogenous latent variable from the structural model, it is feasible to evaluate if an excluded construct substantially influences an endogenous construct. This change is quantified using the effect size $\left(\mathrm{f}^{2}\right)$. The construct's effect size quantifies the influence of the exogenous variable on the structural model's predictive power. According to Cohen (1992), $\mathrm{f}^{2}$ values in the range of $0.02,0.15$, and 0.35 indicate mild, moderate, and significant effects. In our case, $\mathrm{f}^{2}$ values vary from 0.00 to 0.348 . The $\mathrm{f}^{2}$ of the cognitive image is modest when conveying satisfaction $(0.019)$.

Furthermore, the $\mathrm{f}^{2}$ of perceived value $(0.338)$ is significant when explaining satisfaction. Again, loyalty is significant, explaining satisfaction (0.348). Almost none of the other factors (from 0.000 to 0.051 ) had any effect.

Table 6: Effect Size (f $\left.\mathbf{f}^{2}\right)$

\begin{tabular}{|l|l|r|r|r|}
\hline & $\begin{array}{l}\text { Cognitive } \\
\text { Image }\end{array}$ & $\begin{array}{l}\text { Destination } \\
\text { Loyalty }\end{array}$ & $\begin{array}{l}\text { Perceived } \\
\text { Value }\end{array}$ & Satisfaction \\
\hline $\begin{array}{l}\text { Cognitive } \\
\text { Image }\end{array}$ & & 0.005 & 0.076 & 0.019 \\
\hline $\begin{array}{l}\text { Destination } \\
\text { Loyalty }\end{array}$ & & & & \\
\hline $\begin{array}{l}\text { Perceived } \\
\text { Value }\end{array}$ & & 0.051 & & 0.338 \\
\hline Satisfaction & & 0.348 & & \\
\hline
\end{tabular}

\section{Path Coefficients and Significance}

In the SmartPLS bootstrapping approach, subsamples are created randomly from the initial data set (603 representations) with the same sample size as the original sample. To establish the reliability of the results, a large number of subsamples are necessary. The standardized path coefficient was estimated with 5000 iterations using a bootstrapping resampling technique. The structural path diagram depicts the standardized path coefficients at a significance level of $5 \%$. The positive path coefficients for cognitive image and perceived value are significant and positive (Table 7). A similar conclusion was reached regarding the association between cognitive image and satisfaction. There is a positive correlation between perceived value, destination loyalty, and satisfaction. The link between satisfaction and destination loyalty remains strong, indicating significance. In 
contrast, the association between cognitive image and destination loyalty is not statistically significant. Compared to the other components, only satisfaction has a significant effect $(0.523)$ on destination loyalty.

Table: 7 Output of the Structural Model

\begin{tabular}{|c|c|c|c|c|c|}
\hline Hypothesis & Structural Path & $\begin{array}{c}\text { Standardized } \\
\text { coefficient }\end{array}$ & $\begin{array}{c}\mathrm{t}- \\
\text { value }\end{array}$ & P Values & Decision \\
\hline H1 & $\begin{array}{c}\text { Cognitive Image }-> \\
\text { Destination Loyalty }\end{array}$ & 0.052 & 1.451 & 0.147 & $\begin{array}{c}\text { Not } \\
\text { Supported }\end{array}$ \\
\hline H2 & $\begin{array}{c}\text { Cognitive Image }-> \\
\text { Perceived Value }\end{array}$ & 0.265 & 8.044 & 0.000 & Supported \\
\hline H3 & $\begin{array}{c}\text { Cognitive Image }-> \\
\text { Satisfaction }\end{array}$ & 0.121 & 3.267 & 0.001 & Supported \\
\hline H4 & $\begin{array}{c}\text { Perceived Value -> } \\
\text { Destination Loyalty }\end{array}$ & 0.202 & 3.652 & 0.000 & Supported \\
\hline H5 & $\begin{array}{c}\text { Perceived Value -> } \\
\text { Satisfaction }\end{array}$ & 0.504 & 12.47 & 0.000 & Supported \\
\hline H6 & $\begin{array}{c}\text { Satisfaction -> } \\
\text { Destination Loyalty }\end{array}$ & 0.523 & 10.44 & 0.000 & Supported \\
\hline
\end{tabular}

(P values significant at the level of $0.05 ; 0.001$ )

Table 8 shows how perceived value and visitor satisfaction influence cognitive image and destination loyalty. According to the mediation study, perceived value mediates between cognitive image and destination loyalty with $(\beta=0.0535$, $t$-value $=3.55$ at $p$-value 0.00$)$, which is less than $0.05 \%$ significance. Furthermore, the Perceived value mediates the relationship between cognitive image and satisfaction with $(\beta=0.1137, \mathrm{t}$ value $=7.31$ at $\mathrm{p}$ value 0.00 ), which is less than the significance of $0.05 \%$. Again, the mediating impact of satisfaction on perceived value and destination loyalty is significant, with $(\beta=0.264, t$ value $=8.79$, and $p$-value 0.00 ). Furthermore, satisfaction mediates the relationship between cognitive image and destination loyalty with a ( $t$ value of 2.93 and a p-value of 0.00$)$ at the significance level of $0.05 \%$. Finally, perceived value and satisfaction sequentially and positively mediate between cognitive image and destination loyalty with $(\beta=0.07, t$ value $=5.94$, and $\mathrm{p}$-value $0.000<.05$ ).

Table 8: Mediation Analysis of perceived value and satisfaction

\begin{tabular}{|c|c|c|c|c|c|}
\hline Hypothesis & Structural Path & $\begin{array}{c}\text { Standardized } \\
\text { coefficient }\end{array}$ & t-value & P Values & Decision \\
\hline H7 & $\begin{array}{c}\text { Cognitive Image -> Perceived } \\
\text { Value - Destination Loyalty }\end{array}$ & 0.0535 & 3.55 & 0.00 & Supported \\
\hline H8 & $\begin{array}{c}\text { Perceived Value - Satisfaction -> } \\
\text { Destination Loyalty }\end{array}$ & 0.264 & 8.79 & 0.00 & Supported \\
\hline H9 & $\begin{array}{c}\text { Cognitive Image - Perceived } \\
\text { Value - Satisfaction }\end{array}$ & 0.1337 & 7.31 & 0.00 & Supported \\
\hline H10 & $\begin{array}{c}\text { Cognitive Image - Satisfaction -> } \\
\text { Destination Loyalty }\end{array}$ & 0.0632 & 2.93 & 0.003 & Supported \\
\hline H11 & $\begin{array}{c}\text { Cognitive Image - Perceived } \\
\text { Value -> Satisfaction -> Destination } \\
\text { Loyalty }\end{array}$ & 0.07 & 5.94 & 0.00 & Supported \\
\hline
\end{tabular}




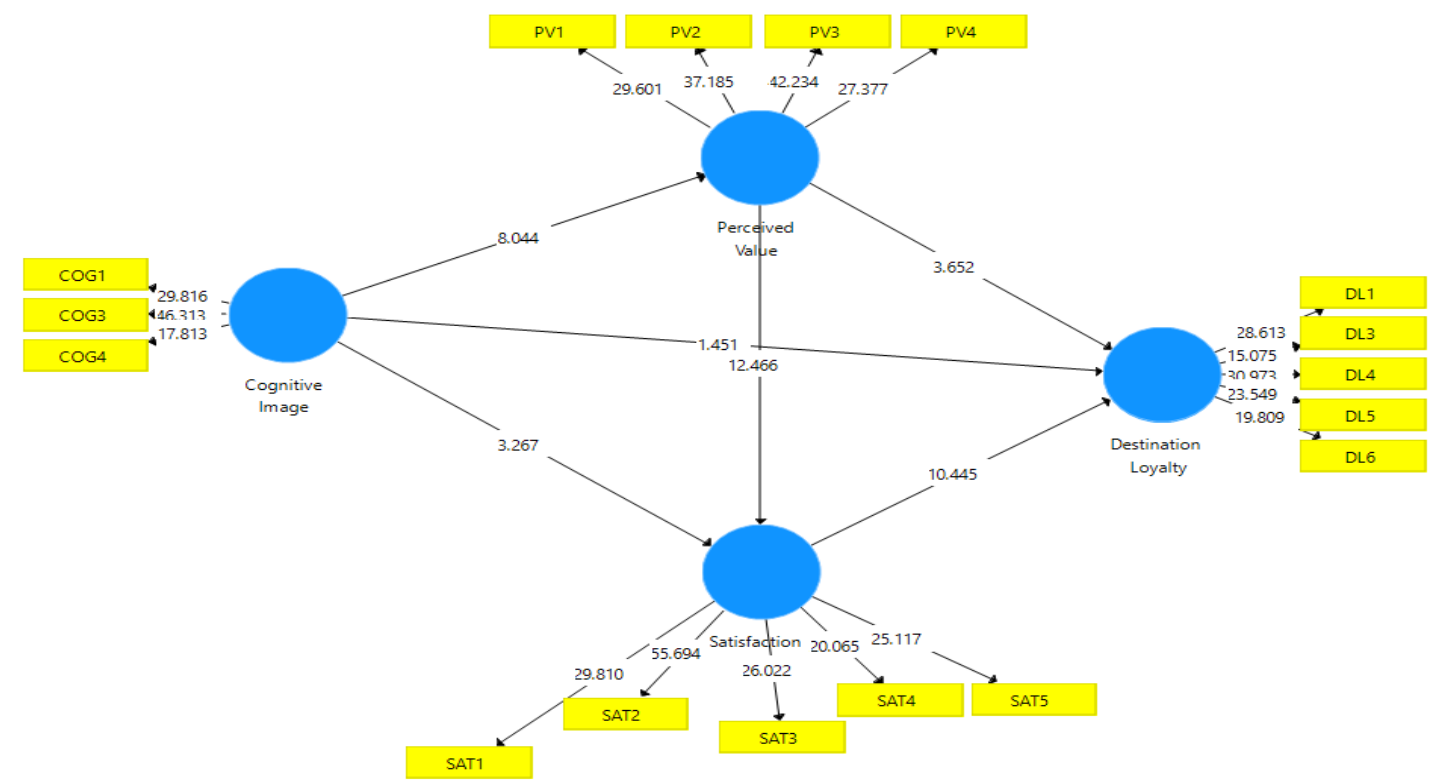

Figure: 2 Bootstrapping Results of the Structural Model

\section{Test of Hypotheses at a Glance}

Ten out of eleven hypotheses are supported in this study.

H1: Cognitive Image has no relationship with destination loyalty showing $\beta=0.052, \mathrm{t}$ value 1.451 , and $\mathrm{p}$ value $=0.147<0.05$. Hence, $\mathrm{H} 1$ is rejected.

H2: Cognitive Image has a significant relationship with the perceived value showing $\beta=0.265$, $t$ value 8.044 , and $p$ value $=0.000<0.05$. Therefore, $\mathrm{H} 2$ is accepted.

H3: Cognitive image positively influences satisfaction showing $\beta=0.121, t=3.267$ and $p$ value $=0.001<0.05$. As a result, $\mathrm{H} 3$ is accepted.

H4: Perceived value positively influences destination loyalty representing $\beta=0.202$, $\mathrm{t}=3.652$, and $\mathrm{p}$ value $=0.000<0.05$. Hense $\mathrm{H} 4$ is supported.

H5: Satisfaction positively influences perceived value representing $\beta=0.504, \mathrm{t}=12.47$, and $\mathrm{p}$ value $=0.000<0.05$. Hence, $\mathrm{H} 5$ is supported.

H6: Satisfaction positively influences destination loyalty representing $\beta=0.523, \mathrm{t}=10.44$ and $\mathrm{p}$ value $=0.00<0.05$. Hence, $\mathrm{H} 6$ is supported.

H7: Perceived value mediates between cognitive image and destination loyalty with $\beta=0.0535, t=3.55$, and $P$ Value $=0.00<0.05$. Therefore, $\mathrm{H} 7$ is supported.

H8: Satisfaction mediates between perceived value and destination loyalty with $\beta=0.264, t=8.79$, and $\mathrm{P}$ Values $0.00<0.05$. Therefore, $\mathrm{H} 8$ is supported.

H9: Perceived value mediates between cognitive image and satisfaction, showing $\beta=0.133, t=7.31$, and $\mathrm{P}$ values $0.00<0.05$. Therefore, $\mathrm{H} 9$ is supported. 
H10: Satisfaction mediates between cognitive image and destination loyalty with $\beta=0.0632, \mathrm{t}=2.93$, and $\mathrm{P}$ values $0.003<0.05$. Therefore, $\mathrm{H} 10$ is supported.

H11: Perceived value and satisfaction sequentially and positively mediates between satisfaction and destination loyalty with $\beta=0.07, t=5.94$, and $p$-value $0.00<0.05$. Therefore, H11 is supported.

\section{Discussion and Implications}

The study investigates the relationship between Cognitive image, perceived value, tourist satisfaction, and destination loyalty in Cox's Bazar. This integrated Model used imagesatisfaction-loyalty and value-satisfaction-loyalty frameworks to assess destination loyalty at Cox's Bazaar. Cox's Bazar's Cognitive image, perceived value, and satisfaction were analyzed to identify critical destination evaluative traits to promote destination loyalty.

The study's outcomes demonstrated a favourable interrelationship between Cognitive image, perceived value, satisfaction, and destination loyalty. However, this research failed to establish a favourable relationship between cognitive image and destination loyalty, consistent with prior research (Bosque \& Martín, 2008). Cox's Bazar's Cognitive image, on the other hand, has a favourable influence on perceived value, which is further corroborated by (Jin et al., 2013). This implies that the destination should have a favourable image since visitors think they are receiving exceptional value for their money from their offerings (Tavitiyaman \& Qu, 2017). In addition, Cox's Bazar Cognitive picture has a considerable influence on visitor satisfaction, which is consistent with previous research (Wang \& Hsu, 2010; Tilaki et al., 2016; Javad et al., 2016 and Chiu et al., 2016).

Furthermore, according to a previous study, perceived value influences tourist satisfaction(Mcdougall et al., 2011; Wang et al., 2017; Chen \& Tsai, 2007) and destination Loyalty (Kim et al., 2013). Moreover, as prior research has shown, satisfaction significantly influences destination loyalty (Chiu et al., 2016; Petrick, 2004; Prayag \& Ryan, 2012). This research proved the previous assumptions of various research.

Another important contribution of this study is to reveal the mediating role of perceived value and satisfaction between cognitive image and destination loyalty. Previously, various studies developed a conceptual framework proving that several factors influence visitor satisfaction, fostering destination loyalty. To yet, insufficient attention has been paid to the impact of perceived value and tourist satisfaction on cognitive image and loyalty. According to the findings of this study, perceived value and satisfaction serve as bridges between cognitive image and loyalty. As a result of the research, perceived value and satisfaction appear to be crucial determinants in determining destination loyalty. Furthermore, this study analyzed multiple mediation effects and affirmed the paths of perceived value and tourist satisfaction on destination loyalty. This study validated the path cognitive image-perceived value-satisfaction and destination loyalty through the parallel mediation, which extended the image-satisfaction-loyalty framework and value-satisfaction and loyalty framework.

This research focused on the tourist sector in a growing destination like Cox's Bazar. As a result, it adds to and broadens the existing information about the tourism industry in a contextual setting. The majority of early tourist research used developed economies as their sample. Because of ethnic diversity, outcomes from one country may 
not be comparable to another, which may have different tastes and expectations based on common cultural or socioeconomic norms.

\section{Managerial Implications}

Identifying the cognitive image that impact perceived value, satisfaction, and destination loyalty can help us comprehend Cox'Bazar's Image. The perceived cognitive image of tourists (great beaches, natural beauty, and pleasant climate) directly influences their satisfaction with Cox's Bazar, but not on destination loyalty. As a result, policymakers, destination marketers, local municipalities, and Cox's Bazar Development Authority must take the necessary efforts to guarantee that tourists have a favorable experience. Tourism enterprises that formerly served various tourist services may be urged to reorient their offerings to attract current, potential and future tourists. These might have been done by developing new products and services, expanding current domestic markets, or identifying new domestic market niches. Cox's Bazar's cognitive image qualities should be improved to attract more tourists, since various research in the literature suggests that cognitive image has a significant effect on a place's emotive image.

The findings have far-reaching consequences for understanding visitor behavior and destination marketing. These findings will likely be helpful to destination marketers, tour operators, and policymakers as they alter current marketing strategies and develop new goods.

\section{Conclusion}

The findings demonstrated that Cox's Bazar's cognitive image had a considerable influence on perceived value and satisfaction. Furthermore, satisfaction and loyalty to a destination are influenced by perceived value. Additionally, perceived value and tourist satisfaction mitigate the influence of a Cox's Bazar cognitive image on destination loyalty. However, no direct relationship was found between Cox's Bazar's cognitive image and destination loyalty. This appears to imply that as long as visitors are satisfied, the image will impact destination loyalty. Tourist satisfaction will also be achieved if tourist services are of excellent quality. As a result, Cox's Bazar, Bangladesh's tourism hotspot and host to the country's longest sea beach, must build an appealing cognitive image, as perceived value and satisfaction are key drivers of travel and promote destination loyalty.

\section{Limitations and Future Directions for Research}

This study employed a convenient sampling strategy during Cox's Bazar's peak season to perform the study. As a result, the outcomes are seasonally constrained. Future studies should be conducted at other times, in different places, and during the off-season to generalize the research findings.

\section{References}

Abdullah, M., Mamun, A. \& Hasan, K. (2013). Image of Cox's Bazar beach as a tourist destination: An Investigation. International Review of Business Research Papers, 9(5), $122-138$.

Allameh, S. M., Khazaei, P. J., Jaberi, A., Salehzadeh, R. \& Asadi, H. (2015). Factors influencing sport tourists revisit intentions: the role and effect of destination image, perceived quality, perceived value and satisfaction. Asia Pacific Journal of Marketing and Logistics, 27(2), 197-207. 
Alegre, J. \& Cladera, M. (2006). Repeat visitation in mature sun and sand holiday destinations. Journal of Travel Research, 44(3), 288-297.

Anderson, J. C. \& Gerbing, D. W. (1988). Structural equation modelling in practice: A review and recommended two-step approach. Psychological Bulletin, 103(3), 411- 423.

Anderson, E. W., Fornell, C. \& Lehman, D. R. (1994). Customer satisfaction, market share, and profitability: Findings from Sweden. Journal of Marketing, 58(3), 53-66. http://doi.org/10.2307/1252310

Baloglu, S. \& McCleary, K.W. (1999) A Model of Destination Image Formation. Annals of Tourism Research, 26, 868-897.

Basaran, U. (2016). Examining the relationships of cognitive, affective and conative destination image: A research on Safranbolu, Turkey. International Business Research, 9(5),164.

Bhattacharjee, A., Polas, M. R. H. \& Rahman, M.L. (2018). Challenges and prospects of tourism in Cox's Bazar: an empirical study. Journal of Business and Technology, 01(XIII), 63-82.

Bigne, J. E., Sanchez, M. I. \& Sanchez, J. (2001). Tourism Image, evaluation variables and after purchase behavior: Interrelationship. Tourism Management, 22, 607-616.

Chen, C.F. \& Phou, S. (2013). A closer look at destination: Image, personality, relationship and loyalty. Tourism Management, 36, 269-278.

Chen, C. F. \& Tasi, D. C. (2007). How destination image and evaluative factors affect behavioral intentions? Tourism Management, 28(4), 1115-1122.

Chen, P. J. \& Krerstetter, D. L. (1999). International students' image rural Pennsylvania as a travel destination. Journal of Travel Research, 37(3), 256-266

Chen, X., Cheng, Z-f. \& Kim, G-B. (2020). Make It Memorable: Tourism Experience, Fun, Recommendation and Revisit Intentions of Chinese Outbound Tourists. Sustainability, 12(5),1904.

Chi, X., Lee, S. K., Ahn,Y-J. \& Kiatkawsin, K. (2020).Tourist perceived quality and loyalty intentions towards rural tourism in china, Sustainability, 12, 3614. http://doi.org/10.3390/su 12093614.

Chin, W.W. (1998). The partial least squares approach to structural equation modelling. In Marcoulides, G. D. (Ed.), Modern Methods for Business Research, Erlbaum, Mahwah, NJ, 295-358.

Chiu, W., Zeng, S. \& Cheng, P. S.T. (2016). The influence of destination image and tourist satisfaction on tourist loyalty: A case study on Chinese tourists in Korea. International Journal of Culture, Tourism, and Hospitality Research.

Cohen, J. (1988). Statistical Power Analysis for the Behavioral Sciences (2nd ed.). Hillsdale, NJ: Lawrence Erlbaum Associates, Publishers.

Cohen, S. A., Prayag, G. \& Moital, M. (2013). Consumer behavior in tourism: Concepts, influences and opportunities. Current Issues in Tourism, 17(10), 872-99.

del Bosque, I. R. \& Martin, H. S. (2008). Tourist satisfaction a cognitive-affective model. Annals of Tourism Research, 35, 551-573.

Diamantopoulos, A. \& Siguaw, J. A. (2006). Formative versus reflective indicators in organizational measure development: A comparison and empirical illustration. British Journal of Management, 17, 263-282.

Echtner, C. M. \& Ritchie, C. R. B. (1993). The measurement of destination image: An empirical assessment. Journal of Travel Studies, 2(2), 2-12. 
Fornell, C. \& Larcker, D. F. (1981). Evaluating structural equation models with unobservable variables and measurement error. Journal of Marketing Research, 18(1), 39-50.

Gallarza, M. G. \& Gill, I. (2006). Value dimensions, perceived value, satisfaction and loyalty: An investigation of university students' travel behavior. Tourism Management, 27,437-452.

Gallarza, M. G., Saura, I. G., \& García, H. C. (2002). Destination image: Towards a conceptual framework. Annals of Tourism Research, 29(1), 56-78.

Gartner, W. C. (1989). Tourism Image:Attribute measurement of state tourism products using multidimensional scaling techniques. Journal of Travel Research, 28(2), 1620.

Hair, J. F., Ringle, C. M., \& Sarstedt, M. (2011). "Pls-sem: indeed, a silver bullet", Journal of Marketing Theory and Practice, 19(2), 139-151.

Hair, J. J. F., \& Sarstedt, M., Hopkins, L., \& Kuppelwieser, G. V. (2014). "Partial least squares structural equation modeling (PLS-SEM): An emerging tool in business research". European, European Business Review, 26(2), 106-121

Hair, J. F. J., Hult, G.T. M., Ringle, C.M., \& Sarstedt, M. (2017). A Primer on Partial Least Squares Structural Equation Modeling(PLS-SEM), $2^{\text {nd }}$ ed., Sage, Thousand Oaks,CA

Hasan, M., Abdullah, S. K., Lew, T-Y., \& Islam, M. (2019). Tourists' satisfaction and destination loyalty: a case study on Cox's Bazar beach of Bangladesh. International Journal of Leisure and Tourism Marketing. 6(3/4).

Henseler, J., Ringle, C. M. \& Sarstedt, M. (2015). A new criterion for assessing discriminant validity in variance-based structural equation modeling. Journal of the Academy of Marketing Science. 43, 115-135.

Iordanova, E., \& Stylidis, D. (2019). The impact of visitors' experience intensity on in-situ destination image formation. Tourism Review, 74(4), 841-860.

Tavitiyaman, P.,\& Qu,H.(2017).Destination Image and Behavior Inetntion of Travelers to Thailand:The Moderating Effect of Perceived Risk, Journal of Travel \& Tourism Marketing, 30(3), 169185.

Tilaki, M. J. M., M., Marzbali, M. H., Abdullah, A. \& Bahauddin, A. (2016). Examining the Influence of International Tourists' Destination Image and Satisfaction on Their Behavioral Intention in Penang, Malaysia. Journal of Quality Assurance in Hospitality \& Tourism, 17(4), 425-452,

Jalilvand, M. R., \& Samiei, N. (2012)."The effect of electronic word of mouth on brand image and purchase intention: An empirical study in the automobile industry in Iran". Marketing Intelligence \& Planning, 30(4), 460-476.

Jenkins, O.H. (1999). Understanding and Measuring Tourist Destination Images, International Journal of tourism research, 1(1), 1-15.

Jeong, Y., \& Kim, S. (2020). A study of event quality, destination image, perceived value, tourist satisfaction, and destination loyalty among sport tourists. Asia Pacific Journal of Marketing and Logistics, 32(4), 940-960.

Jin, N. (Paul), Lee, H., \& Lee, S. (2013). Event Quality, Perceived Value, Destination Image, and Behavioral Intention of Sports Events: The Case of the IAAF World Championship, Daegu, 2011. Asia Pacific Journal of Tourism Research, 18(8), 849-864. 
Kalam, A., \& Hossen, M. A. (2018). Environmentally Sustainable Tourism Problem and Prospects in Bangladesh: A Study on Coastal Region at Cox's Bazar. Journal of Environment and Earth Science, 8(1), 18-25.

Kanwel, S., Lingqiang, Z., Asif, M., Hwang, J., Hussain, A., \& Jameel, A. (2019). The Influence of Destination Image on Tourist Loyalty and Intention to Visit: Testing a Multiple Mediation Approach, Sustainability, 11, 6401,

Kim, S. H., Holland, S., \& Han, H. S. (2013). A structural model for examining how destination image, perceived value, and service quality affect destination loyalty: A case study of Orlando. International Journal of Tourism Research, 15(4), 313-328.

Konecnik, M. (2002). The image as a possible Source of competitive Advantage of the Destination-The Case of Slovenia. Tourism Review, 57(1/2), 6-12.

Kozak, M. (2003). Measuring tourist satisfaction with multiple destination attributes, Tourism Analysis, 7(3-4), 229-240.

Lee, C. K., Yoon, Y. S., \& Lee, S. K. (2007). Investigating the relationships among perceived value, satisfaction and recommendations: The case of the Korean DMZ. Tourism Management, 28(1),204-214.

Li, X., \& Petrick, J. F. (2010). Towards an integrative model of loyalty formation: The role of quality and value. Leisure Sciences, 32(3), 201-221.

Manzoor, F., Wei, L., Asif, M., Haq, M. Z., \& Rehman, H. (2019). The Contribution of Sustainable Tourism to Economic Growth and Employment in Pakistan. International Journal of Environmental Research and Public Health, 16(19), 3785.

Martin, H. S., \& del Bosque, I. A. R. (2008). Exploring the cognitive-affective nature of destination image and the role of psychological factors in its formation, Tourism Management, 29, 263-277.

Mathieson, A., \& Wall, G. (1982). Tourism: Economic, physical, and social impacts. London, New York: Longman. McDougall, G.H.G. \& Levesque, T. (2000) Customer Satisfaction with Services: Putting Perceived Value into the equation. Journal of Services Marketing, 14, 392-410.

Memon, M. A., Ting, H., Cheah, J., Thurasamy, R., Chuah, F. and Cham, T. H. (2020). Sample size for survey research: review and recommendations. Journal of Applied Structural Equation Modeling, 4(2), i-xx.

Merli, R., Preziosi, M., Acampora, A. \& Ali, F. (2019). Why should hotels go green? Insights from guests' experience in green hotels. International Journal of Hospitality Management, 81,169-179.

Mohamad, M., Ab Ghani, N. I., \& Nasir, M. N. M. (2019). The Impact of Perceived Value, Destination Service Quality and Tourist Satisfaction on Destination Loyalty among International Tourists Visiting Malaysia. Journal of Tourism, Hospitality and Environment Management, 4(16), 10-26.

Morgan, N. A., \& Rego, L. L. (2006). The Value of Different Customer Satisfaction and Loyalty Metrics in Predicting Business Performance. Marketing Science, 25(5), 426-439.

Nazir, M. U., Yasin, I., Tat, H. H., \& Khalique, M. (2021). The Influence of International Tourists' Destination Image of Pakistan on Behavioral Intention: The Roles of Travel Experience and Media Exposure International Journal of Hospitality \& Tourism Administration, 00(00), 1-25. 
Oliver, R. L. (1999). Whence consumer loyalty? Journal of Marketing, 63(1) (SUPPL.1), $33-44$.

Ozturk, A.B. \& Qu, H. (2008) The Impact of Destination Images on Tourists' Perceived Value, Expectations, and Loyalty, Journal of Quality Assurance in Hospitality \& Tourism, 9(4), 275-297.

Pavlic, I., \& Peručić, D., \& Portolan, A. (2011). Tourists' satisfaction as an important tool for increasing tourism destination competitiveness in the globalization conditions the case of dubrovnik-neretva county. International Journal of Management Cases. 13.

Petrick, J. F. (2004). Are loyal visitors desired visitors? Tourism Management, 25(4), pp. 463-470

Petrick, J. F. (2002). Development of a Multi-Dimensional Scale for Measuring the Perceived Value of a Service. Journal of Leisure Research, 34(2), 119-134.

Prayag, G., \& Ryan, C. (2012). Antecedents of tourists' Loyalty to Mauritius: The role and influence of destination image, place attachment, personal involvement, and satisfaction. Journal of Travel Research, 51(3), 342-356.

Ramseook-Munhurrun, P., Seebaluck, V. N., \& Naidoo, P. (2015). Examining the Structural Relationships of Destination Image, Perceived Value, Tourist Satisfaction, and Loyalty: Case of Mauritius. Procedia - Social and Behavioral Sciences. 175, 252-259.

Sangipul, A. (2018). The effects of travel experience dimensions on tourist satisfaction and destination loyalty: the case of an island destination, International journal of culture tourism and hospitality research, 12(2).

Shahabuddin, M., Tan, Q., Hossain, I., Alam, S. M., \& Nekmahmud.(2021). Tourist Environmentally Responsible Behavior and Satisfaction; Study on the World's Longest Natural Sea Beach, Cox's Bazar, Bangladesh, Sustainability, 13(16), 9383.

Song, H., \& Chen, J. L. (2012). The Hong Kong tourist. Annals of Tourism Research, 39(1), 459-479.

Song, Z., Su, X., \& Liaoning Li. (2013). The Indirect Effects of Destination Image on Destination Loyalty Intention Through Tourist Satisfaction and Perceived Value: The Bootstrap Approach. Journal of Travel and Tourism Marketing, 30(4), 386409.

Tan, W., \& Wu, C. (2016). An investigation of the relationships among destination familiarity, destination image and future visit intention. Journal of Destination Marketing \& Management, 5(3).

Tavitiyaman, P., \& Qu, H. (2017). Destination Image and Behavior Intention of Travelers to Thailand: the Moderating Effect of Perceived Risk, Journal of Travel \& Tourism Marketing. 30(3), 169-185.

Wang, B., Yang, Z., Han, F., \& Shi, H. (2017). Car tourism in Xinjiang: The mediation effect of perceived value and tourist satisfaction on the relationship between destination image and loyalty. Sustainability, 9(1).

Wang, C. Y., \& Hsu, M. K. (2010). The relationships of destination image, satisfaction, and behavioral intentions: An integrated model. Journal of Travel and Tourism Marketing, 27(8), 829-843. 
Wendy, B., Ka, I., \& Lai, W. (2015). International Journal of Hospitality Management The effects of transaction-specific satisfaction and integrated satisfaction on customer loyalty. International Journal of Hospitality Management, 44, 38-47.

Woodruff, R. B. (1997). Marketing in the 21st Century Customer Value: The Next Source for Competitive Advantage. Journal of the Academy of Marketing Science, 25(3), 256-256.

Yung, R., Lattimore-C., Prayag, G. \& Surovaya, E. (2021). Around the world in less than a day: virtual reality, destination image and perceived destination choice risk in family tourism. Tourism Recreation Research, 46(1), 3-18. 